\title{
Lead concentration and allocation in vegetable crops grown in a soil contaminated by battery residues
}

\author{
Francisco de S Lima; Clístenes WA do Nascimento; Fernando BV da Silva; Vinícius GB de Carvalho; \\ Mateus R Ribeiro Filho \\ UFRPE-Dep ${ }^{\text {to. }}$ Agronomia, R. Dom Manuel de Medeiros s/n, Dois Irmãos, 50171-900 Recife-PE; clistenes@pq.cnpq.br
}

\begin{abstract}
Lead $(\mathrm{Pb})$ is a very stable metal in soil and is highly toxic to humans and animals. Exposure to $\mathrm{Pb}$ occurs via inhalation of particles from industry and soil, as well as household dust, water, and contaminated food. A greenhouse experiment was carried out to evaluate $\mathrm{Pb}$ contents and allocation in vegetable crops grown in a soil contaminated by battery recycling wastes. Eight plant species were studied: tomato, sweet pepper, beet, carrot, cabbage, green collards, eggplant, and okra. The experiment was set up in blocks at random with four replicates. The results showed that carrot, green collards, beet, and okra were the most $\mathrm{Pb}$ tolerant species, while the others were very $\mathrm{Pb}$-sensitive, since they did not complete their cycle. The decreasing order for $\mathrm{Pb}$ accumulation in the vegetables crops was: carrot $>$ okra $>$ tomato $>$ eggplant $>$ sweet pepper $>$ green collards $>$ cabbage $>$ beet. Taking into account the $\mathrm{Pb}$ allocation in plants, the order was: root $>$ stems $>$ leaves $>$ edible parts. Although carrot translocated the lowest $\mathrm{Pb}$ amount into the edible part, such level exceeded the legal limit.
\end{abstract}

Keywords: Battery recycling, soil pollution, soil contamination, heavy metals.

\section{RESUMO}

Teores e alocação de chumbo em hortaliças cultivadas em solo contaminado por resíduos de baterias

$\mathrm{O}$ chumbo $(\mathrm{Pb})$ é um elemento extremamente estável no solo e altamente tóxico para seres humanos e animais. A contaminação com chumbo geralmente ocorre pela exposição decorrente da inalação de partículas oriundas de indústrias ou do solo, ou ainda, pela ingestão de poeira doméstica, água e alimentos de origem animal e vegetal contaminados. O presente trabalho objetivou avaliar os teores e a alocação de $\mathrm{Pb}$ em hortaliças cultivadas em solo contaminado com resíduos de reciclagem de baterias. $\mathrm{O}$ experimento foi conduzido em casa-de-vegetação com delineamento experimental em blocos casualizados, com quatro repetições. Os tratamentos corresponderam a oito hortaliças: tomate, pimentão, beterraba, cenoura, repolho, couve manteiga, berinjela e quiabo. Os resultados mostraram que as espécies mais tolerantes ao $\mathrm{Pb}$ foram cenoura, couve-manteiga, beterraba e quiabo. As demais hortaliças foram consideradas muito sensíveis aos teores de $\mathrm{Pb}$ no solo, não completando inclusive seu ciclo biológico. A ordem decrescente de teores de $\mathrm{Pb}$ nas espécies foi: cenoura $>$ quiabo $>$ tomate $>$ berinjela $>$ pimentão $>$ couve-manteiga $>$ repolho $>$ beterraba. A alocação do $\mathrm{Pb}$ na planta, seguiu a ordem geral: raiz $>$ caule $>$ folha $>$ parte comestível. Embora a cenoura tenha transferido baixo teor de $\mathrm{Pb}$ para a parte comestível, o valor encontrado foi superior ao limite de tolerância máximo estabelecido na legislação.

Palavras-chave: Reciclagem de baterias, contaminação de solo, poluição do solo, metais pesados.

(Recebido para publicação em 16 de julho de 2008; aceito em 11 de agosto de 2009) (Received in July 16, 2008; accepted in August 11, 2009)

$\mathrm{H}$ eavy metals occur naturally in soils, and some of these, such as copper $(\mathrm{Cu})$, zinc $(\mathrm{Zn})$, and cobalt $(\mathrm{Co})$, play an important role in the nutrition of plants and animals, while others, such as cadmium $(\mathrm{Cd})$, lead $(\mathrm{Pb})$, and arsenic (As), have deleterious effects on various components of the biosphere. Normally, these elements are present in the soil at concentrations or forms that do not pose a risk to the environment (Silva et al., 2007), but their levels can be altered by different anthropogenic routes.

Lead is an element that is extremely stable in soil and highly toxic to humans and animals (Reeder \& Shapiro, 2003). The metal is classified as the second most dangerous on the priority list of the U.S. Environmental Protection Agency (ATSDR, 2008). This metal has evoked heightened concern due to its toxicity and high quantity in the environment, caused by its generalized utilization in various products (Segura-Muñoz et al., 2006). The exposure to this element can occur by inhalation of particulate material emitted by industrial processes or by re-suspension after deposition in the soil, or even, through the ingestion of household dust, water, and foods of animal and plant origin produced in locations close to pollutant sources (Okada et al., 2004).

Lead levels found in foods are greater in industrialized regions, especially those where the metal and its components are widely utilized. The preoccupation with lead effects on human health and the environment have led many countries to adopt laws restricting or prohibiting its utilization (Meyer et al., 1999). However, developing countries are not in the vanguard of controlling lead use (Olivero-Verbel et al., 2007). In view of the global scenario of lead utilization, 
it is estimated that the manufacture of batteries is responsible for about $70 \%$ of the lead consumed worldwide. The large worldwide growth in the automobile industry in the last decades (Paoliello \& Chasin, 2001), as well as the expansion of the market for batteries, makes the use and recycling of batteries one of the principal forms of lead contamination in soils.

Lead can occur naturally in plants as a result of the processes of taking up the lead normally found in the soil. Lead forms and contents in vegetables vary greatly with the species and depend principally on the environmental conditions, because contaminated soils can induce lead accumulation by crops (Nan et al., 2002). Lead accumulation by vegetable crops grown in soils with abnormally elevated levels of the metal poses a risk to human health. Therefore, the capacity of these plants to accumulate lead and its presence in edible parts should be evaluated.

Thus, the aim of the present work was to determine lead contents and allocation in vegetables cultivated in soil contaminated with residues from the recycling of batteries.

\section{MATERIAL AND METHODS}

The soil used in the study was a haplic podzol with sandy texture, collected out of an area naturally contaminated with lead $(\mathrm{Pb})$, belonging to a company that recycles batteries. The soil was collected at the surface layer (0-20 cm), and was air-dried, broken up, homogenized, and sifted through a 2-mm mesh screen. Subsamples of the soil were separated for chemical and physical characterization (EMBRAPA, 1997, 1999). The results were: $\mathrm{pH}$ in $\mathrm{H}_{2} \mathrm{O}=3.89 ; \mathrm{P}=2.30 \mathrm{mg} \mathrm{dm}^{-3} ; \mathrm{Na}^{+}=0.28$ $\mathrm{cmol} \mathrm{dm}^{-3} ; \mathrm{K}^{+}=0.05 \mathrm{cmol} \mathrm{dm}^{-3} ; \mathrm{Ca}^{+2}+$ $\mathrm{Mg}^{+2}=5.50 \mathrm{cmol} \mathrm{dm}^{-3} ; \mathrm{Ca}^{+2}=0.90 \mathrm{cmol}_{\mathrm{c}}$ $\mathrm{dm}^{-3} ; \mathrm{Al}^{+3}=0.50 \mathrm{cmol} \mathrm{dm}^{-3} ; \mathrm{H}+\mathrm{Al}=3.30$ $\mathrm{cmol}_{\mathrm{c}} \mathrm{dm}^{-3}$; C.O. $=8.54 \mathrm{~g} \mathrm{~kg}^{-1}$; organic matter $=14.73 \mathrm{~g} \mathrm{~kg}^{-1} ; \mathrm{Pb}=413 \mathrm{mg} \mathrm{kg}^{-1}$; sand $=943 \mathrm{~g} \mathrm{~kg}^{-1}$; silt $=27 \mathrm{~g} \mathrm{~kg}^{-1}$; and clay $=30 \mathrm{~g} \mathrm{~kg}^{-1}$.

To determine the total $\mathrm{Pb}$ level, 10 $\mathrm{ml}$ of extracting solution $\left(\mathrm{HCl}: \mathrm{HNO}_{3}\right.$, in a proportion of $3: 1$ ) were added to $1 \mathrm{~g}$ of soil, and the mixture was allowed to stand in a beaker covered with a watch glass for $16 \mathrm{~h}$, at room temperature. After this period, the samples were heated for $2 \mathrm{~h}\left(80^{\circ} \mathrm{C}\right)$, cooled, brought to $50 \mathrm{~mL}$ in a volumetric flask, and filtered (Pereira et al., 2007). After filtering, the extracts were transferred to PETtype flasks, labeled, and kept at $4^{\circ} \mathrm{C}$ in a refrigerator until read in an atomic absorption spectrophotometer.

The soil was incubated for 20 days with calcium carbonate and magnesium dioxide $(3: 1)$, to raise the $\mathrm{pH}$ to 6.5 . Eight vegetable crops were studied: tomato (Lycopersicum esculentum), cultivar Rio Fuego; sweet pepper (Capsicum annuum), hybrid All Big; beet (Beta vulgaris), cultivar Itapuã 202; carrot (Daucus carota), cultivar Brasília; green collards (Brassica oleracea var. acephala), cultivar Georgia; cabbage (Brassica oleracea var. capitata), cultivar Coração-de-boi; eggplant (Solanum melongena), cultivar Embu; and okra (Abelmoschus esculentus), hybrid Dardo. Seedlings were produced in a greenhouse, in polystyrene foam trays, utilizing Vermicompost as substrate.

To set up the experiments, $5.5 \mathrm{~kg}$ of soil were transferred to a plastic pot and fertilized prior to sowing in accordance with Nascimento et al. (2006). Each pot corresponded to one experimental unit (plot). Twenty days after sowing, seedlings were transplanted to pots, and 15 days after, pots were thinned, leaving three plants per pot. During the study, the soil was kept at $80 \%$ of the maximum water retention, assessed by daily weighing and irrigation to replace the water lost by evapotranspiration. The experiments were carried out in a greenhouse, from January to April 2008, in blocks at random. Treatments corresponded to the eight vegetable crops, with four replications.

The plants were collected, separating roots, stems, leaves, and fruits. Plant parts were thoroughly washed with tap water and then with distilled water. The parts collected were placed in paper bags and set in an oven at $65-70^{\circ} \mathrm{C}$. The dry samples were weighed and then ground in a Wiley type mill. After, samples were submitted to nitroperchloric digestion
(EMBRAPA, 1999) for assessing $\mathrm{Pb}$ levels in the extracts by atomic absorption spectrophotometry. $\mathrm{Pb}$ bioaccumulation rate in the plant, which represents the percentage of the element present in the dry biomass in relation to total content in the soil (Vyslouzilova et al. 2003), was calculated according the formula:

$$
\mathrm{BR}=\frac{\mathrm{Pb}_{\text {plant }}}{\mathrm{Pb}_{\text {soil }}} x 100(\%)
$$

\section{Where}

$\mathrm{Pb}_{\text {plant }}=$ concentration of $\mathrm{Pb}$ in the dry biomass collected $\left(\mathrm{mg} \mathrm{kg}^{-1}\right) ; B_{\text {plant }}$ $=$ total dry biomass collected $(\mathrm{g}) ; \mathrm{Pb}_{\text {soil }}$ $=$ concentration of total $\mathrm{Pb}$ in the soil $\left(\mathrm{mg} \mathrm{kg}^{-1}\right) ; w_{\text {soil }}=$ total amount of soil in pot $(\mathrm{g})$.

The translocation index (TI), in percentage, was calculated as the ratio between the amount of $\mathrm{Pb}$ accumulated in the aboveground part and the total amount in the whole plant (Abichequer \& Bohnen, 1998). Data regarding $\mathrm{Pb}$ contents in the various parts of the crops studied were submitted to analysis of variance and the means were compared by the Scott \& Knott test at $5 \%$ probability.

\section{RESULTS AND DISCUSSION}

The highest $\mathrm{Pb}$ concentration in roots was found in carrots, while green collards and cabbage showed the lowest level of $\mathrm{Pb}$ allocated in the root system (Table 1). Based on these results, carrots represent the crop with least biological restriction in absorbing $\mathrm{Pb}$ from the soil. The difference in the $\mathrm{Pb}$ concentration in roots among the plants analyzed was due to intrinsic characteristics of the crops. Similar results were observed by Al-Lahham et al. (2007), where two cultivars of tomato and their parts differed with respect to the capacity to accumulate heavy metals. This emphasizes the need for studies that indicate the differences in the preferential allocation of this metal in different crops and plant parts.

In examining the $\mathrm{Pb}$ contents in the various plant parts, it is evident that the highest $\mathrm{Pb}$ concentration is found in the roots in all the crops studied. Carrots 
Table 1. Lead concentration in vegetable crops grown in Pb-contaminated soil (Concentração de chumbo nas hortaliças cultivadas em solo contaminado com $\mathrm{Pb}$ ). Recife, UFRPE, 2009.

\begin{tabular}{lcccc}
\hline \multirow{2}{*}{ Crop } & \multicolumn{4}{c}{ Pb Concentration $\left(\mathbf{m g ~ k g}^{-1}\right)$} \\
\cline { 2 - 5 } & Root & Stem & Leaf & Edible part \\
\hline Carrot & $2.162 .1 \mathrm{Aa}$ & $\mathrm{NA}$ & $25.4 \mathrm{Cb}$ & $54.6 \mathrm{Bb}$ \\
Beet & $\mathrm{NA}$ & $\mathrm{NA}$ & $40.3 \mathrm{Bb}$ & $108.3 \mathrm{Aa}$ \\
Tomato & $405.5 \mathrm{Ac}$ & $40.3 \mathrm{Bb}$ & $9.9 \mathrm{Cc}$ & $*$ \\
Sweet pepper & $281.0 \mathrm{Ad}$ & $27.6 \mathrm{Bb}$ & $7.7 \mathrm{Cc}$ & $*$ \\
Green Collards & $175.8 \mathrm{Ae}$ & $10.3 \mathrm{Bc}$ & $3.2 \mathrm{Bc}$ & $3.2 \mathrm{Bc}$ \\
Cabbage & $152.5 \mathrm{Ae}$ & $23.3 \mathrm{Bb}$ & $7.9 \mathrm{Cc}$ & $*$ \\
Okra & $757.2 \mathrm{Ab}$ & $133.5 \mathrm{Ba}$ & $75.7 \mathrm{Ca}$ & $5.2 \mathrm{Dc}$ \\
Eggplant & $389.4 \mathrm{Ac}$ & $37.9 \mathrm{Bb}$ & $7.1 \mathrm{Cc}$ & $*$ \\
\hline CV $(\%)$ & \multicolumn{5}{c}{11.95} \\
\hline
\end{tabular}

Means followed by the same capital letter in the row and small letter in the column do not differ significantly from each other, Scott $\&$ Knott test, $\mathrm{P}<0.05$. (Médias seguidas de mesma letra maiúscula nas colunas e minúscula nas linhas não diferem significativamente entre si, teste de Scott \& Knott, $\mathrm{P}<0,05)$.

$\mathrm{NA}=$ not applicable (não se aplica); * species that did not complete production cycle (espécies que não completaram o ciclo reprodutivo).

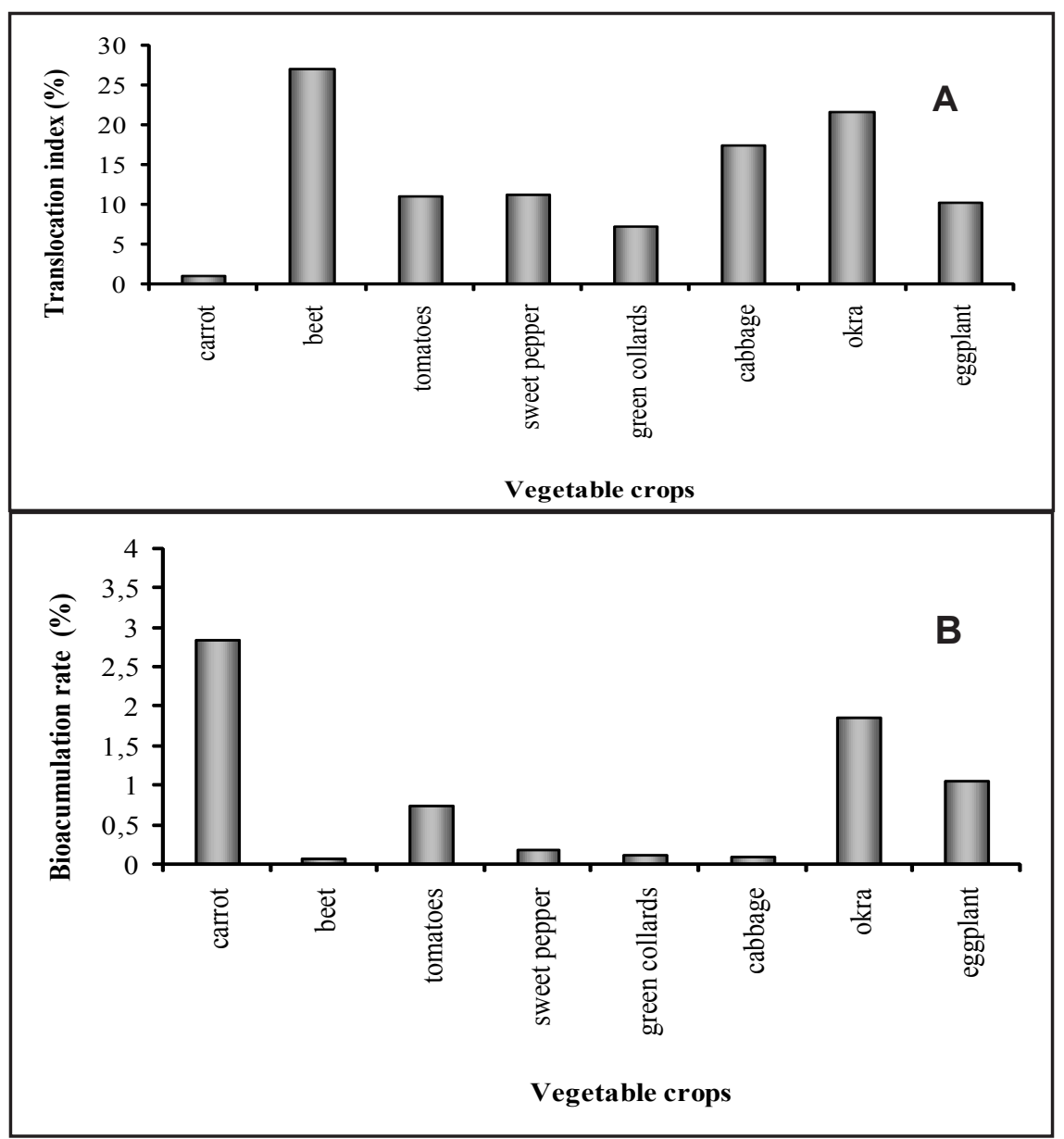

Figure 1. Translocation index (A) and bioaccumulation rate (B) of lead in vegetable crops grown in a contaminated soil. (Índice de translocação (A) e fator de bioacumulação (B) de chumbo em hortaliças cultivadas em solo contaminado). Recife, UFRPE, 2009. accumulated the highest percentage $(96.5 \%)$, followed by green collards (91.3\%), eggplant (89.6), tomato $(88.9 \%)$, sweet pepper $(88.8 \%)$, cabbage $(83.0 \%)$, and okra $(77.9 \%)$. This finding corroborates the characteristic of $\mathrm{Pb}$ in accumulating preferentially in the roots. This metal moves in the root through the apoplast, crossing the cortex, and accumulating close to the endodermis, which acts as a partial barrier in $\mathrm{Pb}$ translocation to the aboveground part. This may be one of the reasons for the greater accumulation of this metal in the roots in relation to the aboveground part (Verma \& Dubey, 2003). The high Pb concentration in roots can also be related to the immobilization of this element by insoluble organic polymers present in the root tissue (Kahle, 1993).

There was no significant difference between the crops studied regarding the $\mathrm{Pb}$ content in stems, except for okra and green collards which showed, respectively, the highest and lowest concentration. This result demonstrates that green collards is the crop that, proportionally, restricts more the allocation of $\mathrm{Pb}$ in the stem, which accumulated only $5.4 \%$ of the total absorbed by the plant.

The analysis of $\mathrm{Pb}$ contents in leaves showed that okra had the highest concentration, followed by carrot and beet, while tomato, pepper, green collards, cabbage, and eggplant concentrated the lowest $\mathrm{Pb}$ amounts. In comparing the $\mathrm{Pb}$ concentration in green collards leaves with the tolerable level of $0.3 \mathrm{mg} \mathrm{kg}^{-1}$ (Codex Alimentarius, 2008), it was found that the consumption of these leaves would pose a potential risk to human health.

On studying the edible parts of the vegetables, it is seen that beet has the highest level of $\mathrm{Pb}$, followed by carrot, while green collards and okra accumulated the lowest $\mathrm{Pb}$ amounts (Table 1). All these $\mathrm{Pb}$ contents in the edible parts are above the tolerance limits established by the Codex Alimentarius (2008): carrot, beet, and okra, $0.1 \mathrm{mg}$ $\mathrm{kg}^{-1}$; and green collards, $0.3 \mathrm{mg} \mathrm{kg}$. Similar results were obtained by Okada et al. (2004) who showed that the $\mathrm{Pb}$ level in the soil caused an increase in $\mathrm{Pb}$ contents in the edible parts of tuber 
vegetables. It is worth noting that (1) the accumulation of $\mathrm{Pb}$ in the edible parts of plants represents a real risk to consumers, and (2) the analysis of the edible parts is definitely the most important to be carried out when human foods is taken into account.

Among the crops evaluated, carrot showed the highest bioaccumulation rate $(2.85 \%)$. In carrots, little of the $\mathrm{Pb}$ absorbed was transferred to the aboveground part of the plant, thereby the remaining accumulated in the roots, as demonstrated by the low translocation index (1.15\%) (Figure 1). On the other hand, among the crops studied, beet showed the lowest bioaccumulation rate $(0.07 \%)$ and highest translocation index $(27.02 \%)$, being the crop that least restricts $\mathrm{Pb}$ to the root. Sweet pepper, green collards, and cabbage showed a behavior that was similar among the three, with a low bioaccumulation rate when compared to tomato, okra, and eggplant.

In general, for all the crops studied, there was a very low bioaccumulation rate of the $\mathrm{Pb}$ present in the soil, due not only to the toxicity of this metal to the plants, but also to its inherent low solubility in the soil (Manecki et al., 2006). However, the highest translocation index observed for some crops should be analyzed with caution due to the possibility of contamination of these vegetables.

Carrot, okra, beet, and green collards, even taking up $\mathrm{Pb}$ from the contaminated soil, completed the cycle without showing visible symptoms of phytotoxicity. It should be noted that the residue deposition in the soil, particularly discharges from the automobile battery industry, can result in metal bioaccumulation in the plant before any phytotoxicity symptom becomes visible (CETESB, 2008). This represents a concern, since vegetables with considerable $\mathrm{Pb}$ contents can be inadvertently consumed.

\section{ACKNOWLEDGEMENTS}

Clístenes WA do Nascimento holds a Productivity in Research fellowship from the National Council for Scientific and Technological Development (CNPq). Authors are grateful to Prof. Adailson Pereira de Souza (UFPB for providing the soil samples. Francisco Lima is grateful to Prof. Joaquim Rufino Neto (IFCE, Crato-CE).

\section{REFERENCES}

ABICHEQUERAD; BOHNEN H. 1998. Eficiência de absorção, translocação e utilização de fósforo por variedades de trigo. Revista Brasileira de Ciência do Solo 22: 21-26.

AL-LAHHAM O; EL ASSI NM; FAYYAD M. 2007. Translocation of heavy metals to tomato (Solanum lycopersicom L.) fruit irrigated with treated wastewater. Scientia Horticulturae 113: 250-254.

ATSDR-Agency for Toxic Substances \& Disease Registry. 2008, 06 de fevereiro. Disponível em: http://www.atsdr.cdc.gov/cercla/05list. html.

CETESB-Companhia de Tecnologia de Saneamento Ambiental. 2008, 01 de junho. Disponível em http://www.cetesb.sp.gov.br/ Solo/vegetacao/poluicao.asp

CODEX ALIMENTARIUS. 2008, 29 de maio. Disponível em: http://www.codexalimentarius. net/web/index_en.jsp

EMBRAPA - Empresa Brasileira de Pesquisa Agropecuária. 1997. Centro Nacional de Pesquisa de Solos (Rio de Janeiro, RJ). Manual de métodos e análises de solo. $2 \mathrm{ed}$. rev. atual. Rio de Janeiro: Embrapa - CNPS. 212p. (Documentos, 1).

EMBRAPA - Embrapa Brasileira de Pesquisa Agropecuária. 1999. Embrapa Comunicação para Transferência de Tecnologia (Brasília, DF). Manual de análises químicas de solos, plantas e fertilizantes. Brasília: Embrapa. 370p. SILVA F C (org.).

KAHLLE, H. 1993. Response of roots of trees to heavy metals. Environmental and Experimental Botany 33(1): 99-119.

MANECKI M; BOGUCKA A; BADJA T; BORKIEWICZ O. 2006. Decrease of $\mathrm{Pb}$ bioavailability in sols by addition of phosphate ions. Environmental Chemistry Letters 3(4): 178-181.

MEYER I; HEINRICH J; LIPPOLD U. 1999. Factors affecting lead, cadmium, arsenic levels in house dust in a smelter town in Eastern Germany. Environmental Research 81(1):32-44.
NAN Z; ZHAO C; LI J; CHEN F; SUN, W. 2002. Relations between soil properties and elected heavy metal concentrations in spring wheat (Triticum aestivum L.) grown in contaminated soils. Water, Air, Soil Pollution 133:205-213.

NASCIMENTO CWA; AMARASIRIWARDENA D; XING B. 2006. Comparison of natural organic acids and synthetic chelates at enhancing phytoextraction of metals from a multi-metal contaminated soil. Environmental Pollution 140:114-123.

OKADA IA; DURAN MC; KIRA CS; MAIO FD; SAKUMA AM; TIGLEA P; PEREIRA MLS. 2004. Chumbo em alimentos produzidos no entorno de uma empresa recicladora de baterias no município de Bauru, estado de São Paulo, Brasil, Revista Instituto Adolfo Lutz 63(1): 87-90.

OLIVERO-VERBEL J; DUARTE D; ECHENIQUE M; GUETTE J; JOHNSONRESTREPO B; PARSONS P. 2007. Blood lead levels in children aged 5-9 years living in Cartagena, Colombia. The Science of the Total Environment 372:707-716.

PAOLIELLO MMB; CHASIN AAM. 2001. Ecotoxicologia do chumbo e seus compostos. Salvador: CRA. 144p. (cadernos de referência ambiental; v. 3).

PEREIRA JC; GUIMARÃES-SILVA AK; NALINI JÚNIOR A; PACHECO SILVA E; LENA JC. 2007. Distribuição, fracionamento e mobilidade de elementos traço em sedimentos superficiais. Química Nova 30(5): 12491255.

REEDER P; SHAPIRO L. 2003. Lead contamination of soils in Belize City, Belize, Central America. Journal Environmental Science Health 38:2785-2805.

SEGURA-MUÑOZ SI; SILVA OLIVEIRA A; NIKAIDO M; TREVILATO TMB; BOCIO A; TAKAYANAGUI AMM; DOMINGO JL. 2006. Metal levels in sugar cane (Saccharum spp.) samples from an area under the influence of a municipal landfill and a medical waste treatment system in Brazil. Environmental International 32(1):52-57.

SILVA ML de S; VITTI GC; TREVISAM AR. 2007. Concentração de metais pesados em grãos de plantas cultivadas em solo com diferentes níveis de contaminação. Pesquisa Agropecuária Brasileira 42(4):527-535.

VERMA S; DUBEY R S. 2003. Lead toxicity induces lipid peroxidation and alters the activities of antioxidant enzymes in growing rice plants. Plant Science 164(4): 645-655.

VYSLOUŽILOVÁ M; TLUSTOŠ P; SZÁKOVÁ J. 2003. Cadmium and zinc phytoextraction potential of seven clones of Salix spp. planted on heavy metal contaminated soils. Plant Soil Environment 49:542-547. 